\title{
Permeability of Dictyostelium discoideum towards Amino Acids and Inulin: a Possible Relationship between Initiation of Differentiation and Loss of 'Pool' Metabolites
}

\author{
By K.-C. LEE* \\ Sub-Department of Chemical Microbiology, Department of Biochemistry, \\ University of Cambridge, Cambridge
}

(Received 27 January 1972)

\begin{abstract}
SUMMAR Y
The permeability of Dictyostelium discoideum amoebae towards amino acids and inulin was studied under conditions suitable for development of aggregationcompetence and in thick cell suspensions. During the pre-aggregation period, the amoebae released large amounts of amino acids and nucleotides into the suspending medium. The uptake of glutamate and lysine by amoebae was passive, but inulin was taken up actively, probably by pinocytosis. Hence the simplest explanation for leakage of metabolites is that the amoebae have no active mechanism for retaining them. A possible relationship between initiation of differentiation and loss of pool metabolites is discussed.
\end{abstract}

\section{INTRODUCTION}

When vegetative cells of the cellular slime mould, Dictyostelium discoideum, are placed on a non-nutrient surface, they aggregate after a lag of 6 to $7 \mathrm{~h}$ to form multi-cellular aggregates which eventually produce spore-bearing fruiting bodies. Unlike many other organisms used for the study of development, the cell-proliferation (unicellular) phase and the differentiation (multicellular) phase are separate, and it is possible to study the development of aggregation-competence and accompanying biochemical events in the absence of growth (Bonner, I967; Sussman \& Sussman, 1969; Newell, 1971).

Differentiation in Dictyostelium discoideum is generally believed to be initiated by starvation, but the molecular events have not been elucidated. The amoebae lose $50 \%$ of their dry weight during morphogenesis from vegetative cells to mature fruiting bodies, and there is breakdown and re-utilization of cell constituents (White \& Sussman, I96I; Sussman \& Sussman, 1969). Krichevsky \& Love (1965) and Krichevsky, Love \& Chassy (1969) reported an efflux of acid-insoluble protein and RNA from $D$. discoideum amoebae incubated in distilled water, and that this efflux was reduced by substances which stimulated the 'rate of morphogenesis'. Hence it appeared that retention of macromolecules for endogenous utilization inside the amoebae accelerated the rate of differentiation. However, this efflux of macromolecules was not linear and showed large unexplained oscillations. These authors prepared their cell-free supernatant fluid containing the released macromolecules by vacuum filtration through Millipore filters. In a preliminary investigation it was found that considerable lysis occurred during filtration of the amoebal suspension through Millipore filters, but when amoebae were removed by centrifugation, lysis did not occur and no acid-insoluble material was detectable in the supernatant fluid. It is probable

* Present address: Department of Biochemistry, University of Alberta, Edmonton, Alberta, Canada. 
that the efflux of macromolecules reported (Krichevsky \& Love, 1965; Krichevsky et al. I969) was caused by cell breakage during filtration.

In the absence of reliable information on the uptake and release of metabolites by Dictyostelium discoideum, an investigation along these lines was undertaken in the hope that it would throw light on the initiation of differentiation. However, there are practical problems. It is desirable to study uptake and release of metabolites in cell suspensions, but previous work on cellular slime mould differentiation was performed mostly on a solid surface. Aggregation of D. discoideum will occur in submerged cultures (Bonner, 1947), but aggregates develop into slugs and sorocarps only if they are in contact with air. Nevertheless, experiments involving uptake of radioactive compounds have been performed in suspension after the amoebae had been washed off agar or Millipore filters and dispersed (Pannbacker, 1967; Sargent \& Wright, 1971). This was done to ensure intimate contact between amoebae and medium, but morphogenesis was halted and experimental data obtained under these conditions may not be representative of undisturbed amoebae.

\section{METHODS}

\section{Growth and differentiation of Dictyostelium discoideum}

Dictyostelium discoideum AX-2 (kindly supplied by Dr J. M. Ashworth, Department of Biochemistry, The University, Leicester) was grown aerobically in a protease peptoneyeast extract-glucose medium as described by Schwalb \& Roth (1970) and Watts \& Ashworth (1970). The amoebae were harvested during the exponential phase of growth $\left(6 \times 10^{6}\right.$ amoebae $\left./ \mathrm{ml}\right)$ by centrifugation $(300 \mathrm{~g}, 2 \mathrm{~min})$.

Differentiation was followed in suspension and on a solid surface. For examination of differentiation in suspension, the amoebae were washed and suspended at $10^{7}$ amoebae $/ \mathrm{ml}$ in non-nutrient media specified in the legends to figures and incubated aerobically at $23{ }^{\circ} \mathrm{C}$ in an orbital incubator ( $150 \mathrm{rev} . / \mathrm{min}$ ).

Two methods were used for following differentiation on a solid surface. Exponential phase amoebae were washed and suspended in ice-cold medium $\mathrm{M}$ (IO $\mathrm{mM}-\mathrm{KCl}, 5 \mathrm{mM}$ $\mathrm{MgCl}_{2}$, Io mM-sodium phosphate, $\mathrm{pH} 60^{\circ}$ ). Three $\mathrm{ml}$ of the suspension containing $\mathrm{IO}^{7}$ amoebae were pipetted into a $6 \mathrm{~cm}$ Falcon plastic tissue-culture dish. The amoebae soon settled to the bottom, and were not resuspended by slight movement of fluid in the dish. The presence of $\mathrm{Mg}^{2+}$ was essential for firm attachment of the amoebae to the bottom of the dish. The dish was incubated statically in the dark at $23^{\circ} \mathrm{C}$. Under these conditions, the formation of streams and aggregation centres was detectable after 9 to Io $\mathrm{h}$ and aggregation completed by 16 to $20 \mathrm{~h}$.

In other experiments, differentiation was followed microscopically on a coverslip. A perspex ring ( $13 \mathrm{~mm}$ internal diameter, $2 \mathrm{~mm}$ thickness) was fixed on to a $22 \times 22 \mathrm{~mm}$ glass coverslip with soft paraffin wax. One drop of amoebal suspension (106 amoebae $/ \mathrm{ml}$ ) was placed on the coverslip inside the ring. After $5 \mathrm{~min}$, the drop was sucked off leaving a single well-dispersed layer of amoebae on the coverslip. The coverslip was rapidly inverted over a glass slide. A small drop of the suspending medium on the slide ensured a humid atmosphere inside the chamber which was sealed with paraffin wax. Under these conditions (at $23{ }^{\circ} \mathrm{C}$ ), the amoebae in a thin film of fluid on the coverslip will go through the whole developmental sequence. 


\section{Uptake of amino acids in dilute amoebal suspensions}

Amoebae were incubated in suspension in medium $\mathrm{M}$ at a density of $10^{7}$ amoebae $/ \mathrm{ml}$ in the presence of radioactively labelled amino acids. At various times, samples were diluted into ro vol. of medium $\mathrm{M}$ at $0^{\circ} \mathrm{C}$, centrifuged $\left(300 \mathrm{~g}, 5 \mathrm{~min}, 4{ }^{\circ} \mathrm{C}\right)$, and the supernatant. fluid decanted off. The pellets were washed twice with medium $\mathrm{M}\left(0^{\circ} \mathrm{C}\right)$ and suspended in distilled water at $0^{\circ} \mathrm{C}$. Samples were taken for radioactive measurement of total uptake. The remaining amoebae were precipitated with $0.2 \mathrm{M}$-perchloric acid (PCA), and washed once with $0.2 \mathrm{M}-\mathrm{PCA}$ and $\mathrm{I} \%(\mathrm{v} / \mathrm{v})$ acetic acid at $0^{\circ} \mathrm{C}$. The precipitates were dissolved in $\mathrm{I} \cdot \mathrm{O} \mathrm{M}$-ammonium hydroxide. All samples were dried on aluminium planchets, and the radioactivity estimated by means of a Nuclear Chicago gas-flow counter.

\section{Uptake of lysine in thick amoebal suspensions}

The procedure was based on the method described by Mitchell (1953). Amoebae were washed twice in medium $\mathrm{M}\left(0^{\circ} \mathrm{C}\right)$ containing unlabelled lysine at the concentration to be used for measurement of uptake, and centrifuged ( $1000 \mathrm{~g}$, I $5 \mathrm{~min}, 4^{\circ} \mathrm{C}$ ) in a Io $\mathrm{ml}$ graduated conical centrifuge tube. The pellet volume was noted, and the supernatant fluid removed completely. A volume of ice-cold medium $\mathrm{M}$ equal to the pellet volume, but containing radioactively labelled lysine, was added to the pellet. The amoebae were suspended by agitation with the aid of a thin glass rod. A sample of the suspension was centrifuged immediately ( $1000 \mathrm{~g}, \mathrm{I} 5 \mathrm{~min}, 4^{\circ} \mathrm{C}$ ), and $50 \mu \mathrm{l}$ samples of the supernatant fluid were taken for assay of radioactivity. The remaining amoebae were warmed to $23{ }^{\circ} \mathrm{C}$ and incubated in a $50 \mathrm{ml}$ conical flask at $23^{\circ} \mathrm{C}$ in an orbital incubator (I50 rev./min). Samples were taken at intervals, centrifuged to remove amoebae, and the supernatant fluid assayed for radioactivity. The supernatant fluid $(50 \mu \mathrm{l})$ was mixed with $15 \mathrm{ml} \mathrm{2,5}$-bis $\left(5^{\prime}\right.$-tert-butylbenzoxazolyl-2')thiophene (BBOT)-toluene/Triton (2 vol. toluene containing $4 \mathrm{~g}$ BBOT/ 1: I vol. Triton $\mathrm{X}-\mathrm{IOO}$ ) in a glass scintillation vial and the radioactivity determined with a Philips liquid scintillation analyser. The analyser was programmed for simultaneous measurement of carbon-I 4 and tritium. Two series of quenched standards (one for each isotope) were used to determine the parameters for the calculator programme.

\section{Analytical methods}

Protein was determined by the method of Lowry, Roseborough, Farr \& Randall (I95I) with bovine serum albumin as standard. RNA was assayed by the orcinolimethod (Munro \& Fleck, 1966) with D-ribose as standard, and amino acids by the ninhydrin reaction (Rosen, 1957) with L-leucine as standard. Samples for determination of total phosphorus were charred, oxidized and hydrolysed (Leloir \& Cardini, 1957), and the inorganic phosphate produced was assayed by the method of Stanton (I968).

\section{Materials}

Radiochemicals were supplied by the Radiochemical Centre, Amersham, Buckinghamshire.

\section{RESULTS}

\section{Development of aggregation-competence in dilute amoebal suspensions}

Gerisch (1962, 1968), working with Dictyostelium discoideum amoebae grown on Escherichia coli in shaken suspensions, found that the amoebae, although physically prevented from aggregating, attained maximum aggregation-competence $9 \mathrm{~h}$ after exhaustion of bacteria. Since the experiments reported here were performed on amoebae grown 

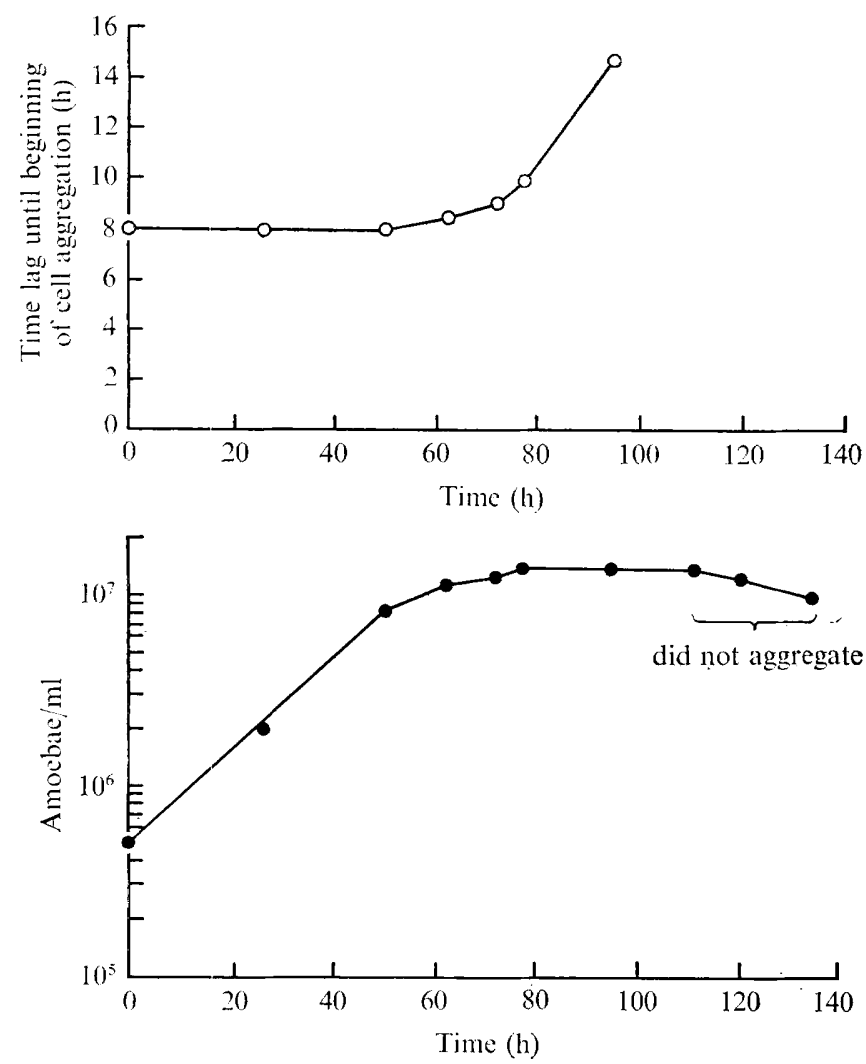

Fig. I. Variation of aggregation-competence with age of culture. Amoebae from an exponentially growing culture were inoculated into fresh medium at an initial cell density of $5 \times 10^{5} / \mathrm{ml}$ and incubated at $23{ }^{\circ} \mathrm{C}$ in an orbital incubator ( $150 \mathrm{rev} . / \mathrm{min}$ ). At various times, amoebae were transferred to a coverslip, washed in medium $\mathrm{M}$ and incubated at $23{ }^{\circ} \mathrm{C}$. The times of appearance of the first aggregation streams were recorded.

axenically, it was necessary to reinvestigate this problem in order to characterize the differentiation of these amoebae in suspension.

Amoebae harvested at various times during the exponential and stationary phase of growth were transferred to coverslips in a non-nutrient medium and incubated in a humid chamber. The times of appearance of the first aggregation streams were recorded (Fig. I). The time taken for aggregation to occur was constant for amoebae harvested during the exponential phase of growth. This result is different from that of Gerisch (1962, 1968) in that after cessation of growth there was a progressive increase instead of a decrease in the time taken for appearance of aggregation streams. After $60 \mathrm{~h}$ in the stationary phase, the amoebae were no longer capable of aggregation.

When exponential-phase amoebae were washed and incubated in a variety of nonnutrient media, aggregation-competence developed in a way analogous to that with bacteriagrown amoebae (Fig. 2). There was a considerable variation in the results, but the amobae always reached the aggregation stage faster with increasing periods of incubation. On further incubation, amoebae in some media (e.g. distilled water) lost their aggregationcompetence faster than others.

It is evident that the biochemical events associated with development of aggregation- 


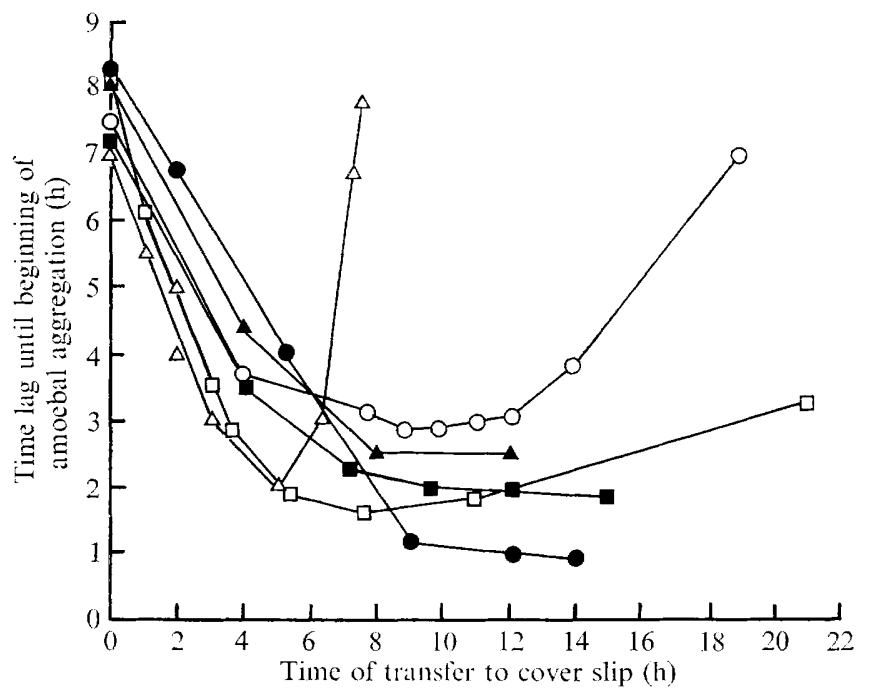

Fig. 2. Development of aggregation-competence in non-nutrient media. Exponential-phase amoebae were washed and suspended at $10^{7} \mathrm{cells} / \mathrm{ml}$ in the media indicated and incubated at $23^{\circ} \mathrm{C}$ in an orbital incubator ( $150 \mathrm{rev} . / \mathrm{min}$ ). At various times, samples of cells were transferred to coverslips and incubated at $23{ }^{\circ} \mathrm{C}$. The times at which aggregation occurred were recorded. $\boldsymbol{0}, 10 \mathrm{~mm}$-sodium phosphate (pH 6.8); O, Bonner's salt solution (I0 mM- $\mathrm{NaCl}$, Io mM- $\mathrm{KCl}, 2.7 \mathrm{~mm}-\mathrm{CaCl}_{2}$ ); ,

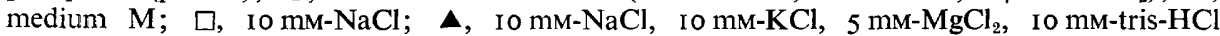
$(\mathrm{pH} 7 \cdot 0) ; \triangle$, distilled water.

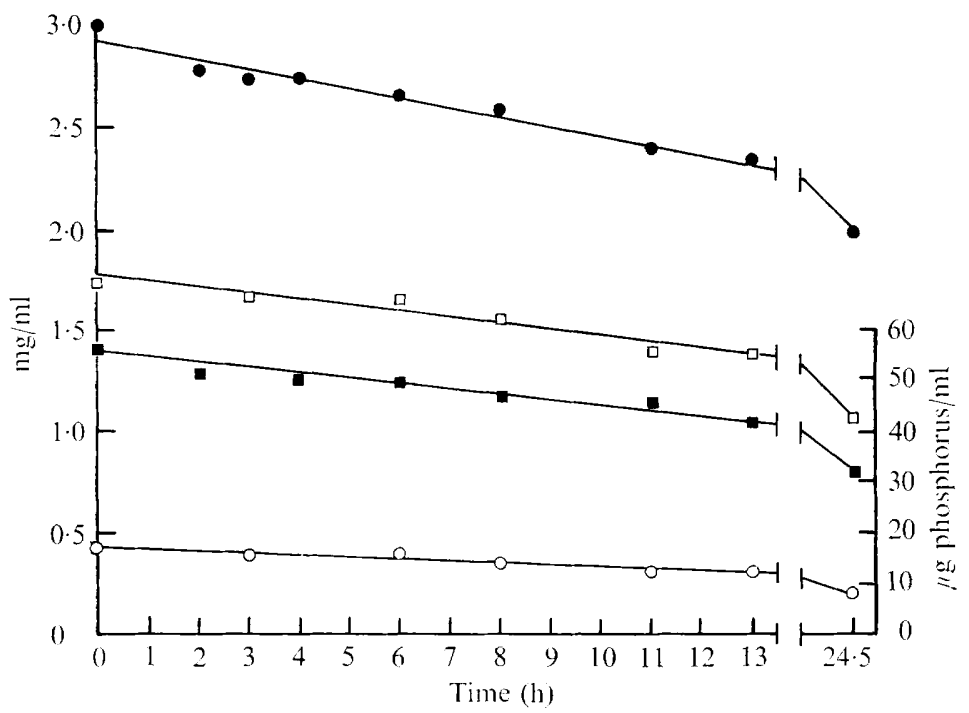

Fig. 3. Changes in cellular constituents during incubation in suspension. Exponential-phase amoebae were incubated in suspension at $10^{7}$ cells $/ \mathrm{ml}$ in $10 \mathrm{~mm}-\mathrm{NaCl}, 10 \mathrm{~mm}-\mathrm{KCl}, 5 \mathrm{~mm}-\mathrm{MgCl}_{2}$, Io mM-tris- $\mathrm{HCl}(\mathrm{pH} 7 \cdot 0)$. Samples were taken at intervals for determination of dry weight, phosphorus, RNA and protein content. Dry weight was determined in amoebae washed once and suspended in distilled water and dried to constant weight at $105^{\circ} \mathrm{C}$. Protein and RNA were determined in cells precipitated and washed with $0.2 \mathrm{M}$-PCA. RNA was extracted with $0.5 \mathrm{M}-\mathrm{PCA}$ ( $70^{\circ} \mathrm{C}, 30 \mathrm{~min}, 3$ times), and the residue was dissolved in $1.0 \mathrm{M}-\mathrm{NaOH}$ for determination of protein content. Dry weight; $\square$, protein; $\mathbf{\square}$, phosphorus; $O$, RNA. 

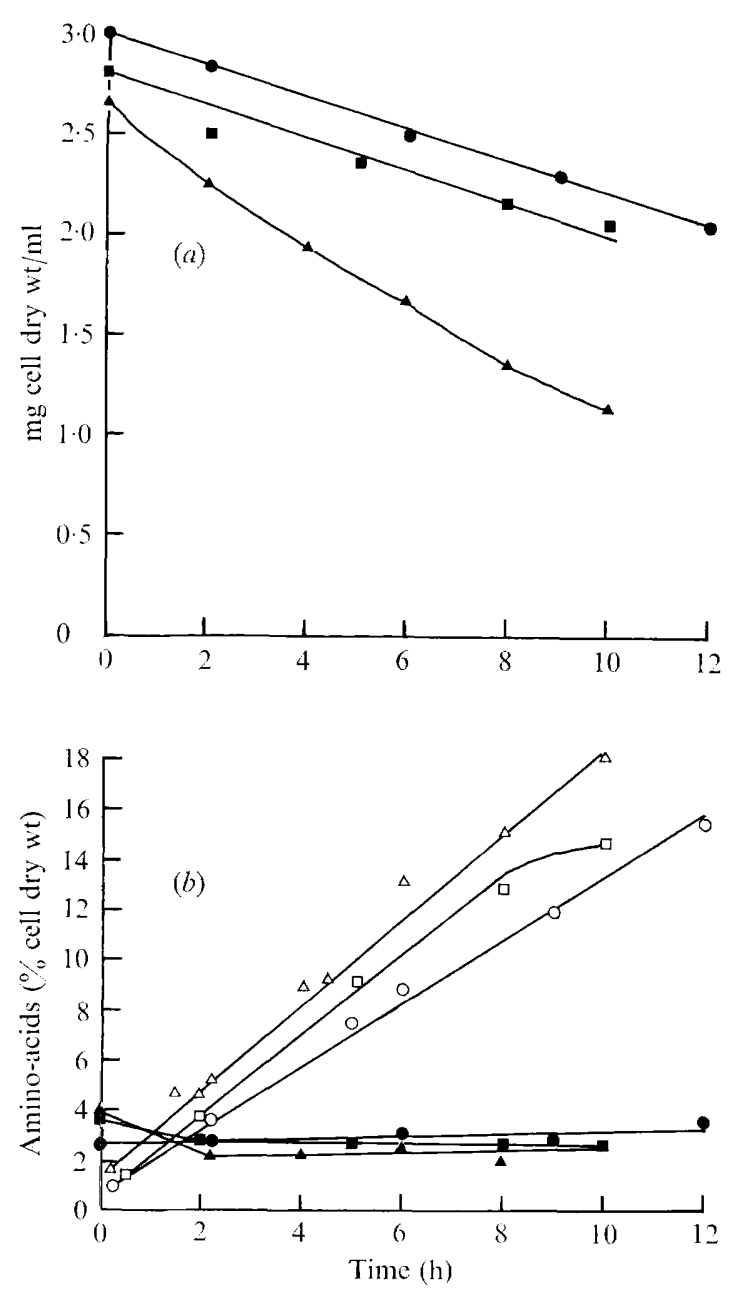

Fig. 4. Efflux of amino acids from amoebae incubated in suspension. Exponential-phase amoebae were incubated in suspension at $10^{2}$ cells $/ \mathrm{ml}$ in medium $\mathrm{M}$, Io $\mathrm{mM}-\mathrm{NaCl}$ or distilled water. Samples were taken at various times for determination of dry weight (Fig. 3) and assay of amino acids in the supernatant fluid and the hot-water-extractable pool (100 $\left.{ }^{\circ} \mathrm{C}, 15 \mathrm{~min}\right)$. The average molecular weights used for calculation of the weights of amino acids were estimated from the amino acid compositions of pool and supernatant fluid. (a) Dry weight of amoebae incubated in: -, medium M; $\mathbf{\square}, 10 \mathrm{mM}-\mathrm{NaCl} ; \boldsymbol{\Lambda}$, distilled water. (b) Amino acid content in the supernatant fluid (\% initial cell dry wt): $\mathrm{O}$, medium $\mathrm{M} ; \square, \mathrm{I}$ o $\mathrm{mM}-\mathrm{NaCl} ; \Delta$, distilled water. Amino acid content in the pool ( $\%$ cell dry wt at times indicated): $\bullet$, medium $\mathrm{M} ; \mathbf{\square}, 10 \mathrm{mM}-\mathrm{NaCl} ; \boldsymbol{\Lambda}$, distilled water.

competence can be conveniently studied in amoebal suspensions, but it is important to note that aggregation-competence is not identical with aggregation and some biochemical events are linked to morphogenetic events or 'normal cell contacts' (Sussman, I968; Newell, Longlands \& Sussman, I97I).

\section{Release of amino acids}

Dictyostelium discoideum amoebae lose about $50 \%$ of their dry weight during morphogenesis from vegetative cells to mature sorocarps without changes in the relative proportions of protein and RNA (White \& Sussman, 196I). An analogous situation was observed 
in amoebae incubated in suspension (Fig. 3). The density of amoebae in the suspension showed a slight increase, and no lysis was detected microscopically. The proportions of protein, RNA and phosphorus were practically constant $(60 \%, \mathrm{I} 4 \%$ and $\mathrm{I} \cdot 9 \%$ dry wt respectively) despite large reductions in amoebal size and dry weight. These results suggest that the amoebae were functionally intact when incubated in suspension. In the above experiment tris- $\mathrm{HCl}$ was used as buffer instead of phosphate in medium $\mathrm{M}$ for convenience of phosphate analysis, but there is no evidence that amoebae in tris-buffered medium behaved differently from those in medium $\mathrm{M}$ as far as development of aggregation-competence was concerned (Fig. 2).

Contrary to the reports of Krichevsky et al. (1969), there was no efflux of acid-precipitable material from amoebae in non-nutrient media, but large amounts of ninhydrin-positive and u.v.-absorbing material were detected in the suspending media. The efflux of ninhydrinpositive material was linear for at least $8 \mathrm{~h}$ with slightly different rates in different media (Fig. 4). The amount of pool ninhydrin-positive material of amoebae in medium $\mathrm{M}$ was constant at about $3 \%$ dry wt, but that of amoebae in distilled water and $10 \mathrm{mM}-\mathrm{NaCl}$ fell during the first $2 \mathrm{~h}$ and remained at a lower level thereafter. When the amino acids released during a $4 \mathrm{~h}$ incubation were assayed with an amino acid analyser, it was found that they accounted for $85 \%$ to $90 \%$ of the ninydrin-positive material present in the suspending medium. The relative proportions of the amino acids released varied with the suspending medium and were different from those of the pool.

The amounts of amino acids released by amoebae in distilled water, $10 \mathrm{~mm}-\mathrm{NaCl}$ and medium $\mathrm{M}$ during a $10 \mathrm{~h}$ incubation were $17 \%, \mathrm{I} 4 \%$ and $12.6 \%$ of the initial dry weight respectively. Assuming that the proportion of protein in amoebae remained constant at $60 \%$ dry weight, the corresponding decreases in protein content calculated from decreases in dry weight were $33.9 \%, 17.1 \%$ and $16.0 \%$. It is evident that, when amoebae were incubated in $10 \mathrm{~mm}-\mathrm{NaCl}$ or medium $\mathrm{M}$, about $80 \%$ of the decrease in cell protein could be accounted for by the appearance of amino acids in the suspending medium. When amoebae were incubated in distilled water, the decrease in their dry weight was not accounted for by a proportionate release of amino acids. This could result from amoebae losing their viability and having a different pattern of metabolism, because amoebae in distilled water reached maximum aggregation-competence in only $5 \mathrm{~h}$, but after $8 \mathrm{~h}$ had completely lost the ability to aggregate (Fig. 2). This rapid loss of aggregation-competence may have been a secondary effect of depletion of essential salts and was unlikely to have been solely the result of the loss of amino acids because the rates of leakage in $10 \mathrm{mM}-\mathrm{NaCl}$ and distilled water were similar and not much higher than that in medium $M$.

It is clear from Fig. 3 that there was a loss of phosphorus compounds from amoebae incubated in a non-nutrient medium. Using ${ }^{32} \mathrm{P}$-labelled cells, it was found that the decrease in phosphorus content of amoebae could be accounted for by the appearance of low molecular weight phosphorus compounds in the suspending medium. These compounds were shown by paper chromatography in iso-propanol- $\mathrm{HCl}$ to be a mixture of nucleotides and orthophosphate.

\section{Uptake of amino acids in dilute suspensions}

The depletion of amoebal constituents during the pre-aggregation period could act as a trigger to the initiation of differentiation. It has been repeatedly demonstrated that incorporation of radioactively labelled precursors of cell constituents occurs during differentiation and metabolites must therefore flow in and out of cells. The uptake of amino acids was studied because they were released in large amounts during the pre-aggregation period 


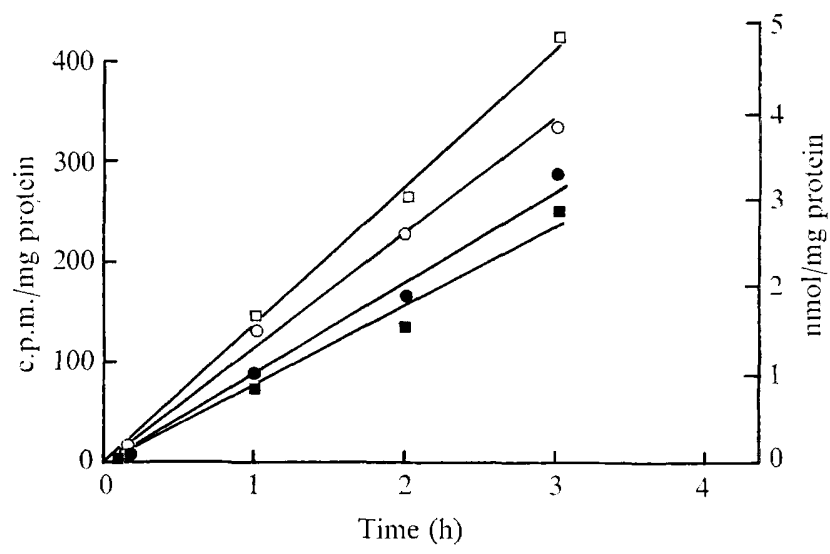

Fig. 5. Uptake of glutamate by exponential-phase amoebae. Exponential-phase amoebae were incubated in dilute suspensions in medium $M$ with or without $1.5 \%(\mathrm{w} / \mathrm{v})$ glucose in the presence of L-[U- $\left.{ }^{14} \mathrm{C}\right]$ glutamate $(0.4 \mu \mathrm{Ci} / \mathrm{ml}$, I mM). Samples were taken at various times for assay of radioactivity in amoebae and PCA-precipitates. Control: $\bigcirc$, cells;, , PCA-precipitate. Treatment with glucose: $\square$, cells; $\mathbf{\square}$, PCA-precipitate.

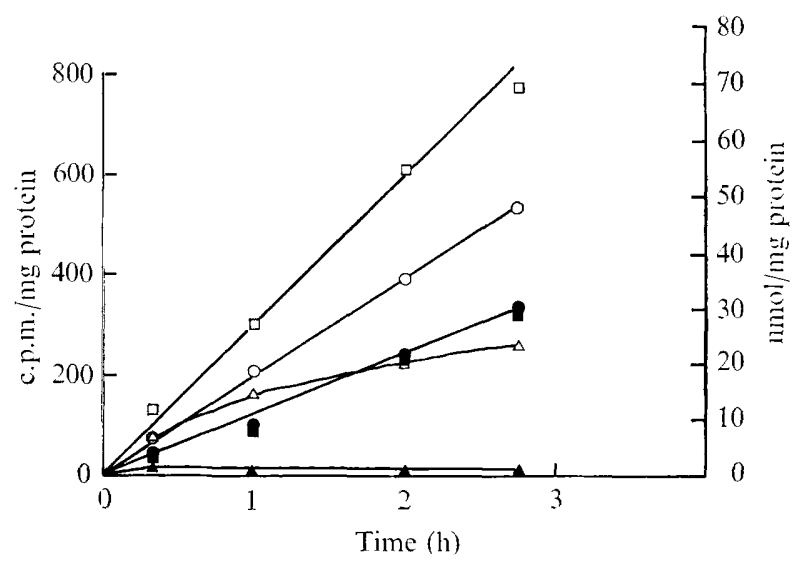

Fig. 6. Uptake of lysine by exponential-phase amoebae. Exponential-phase amoebae were incubated in dilute suspensions in medium $M$ containing $L-\left[U-{ }^{14} \mathrm{C}\right]$ lysine $(0.2 \mu \mathrm{Ci} / \mathrm{ml}, 5 \mathrm{~mm})$ with additions of glucose $\left(1.5 \%\right.$, w/v) or DNP $\left(5 \times 10^{-4} \mathrm{M}\right)$. Samples were taken at various times for assay of radioactivity in cells and PCA-precipitates. Control: $O$, cells; 9 , PCA-precipitate. Treatment with glucose: $\square$, cells; $\mathbf{\square}$, PCA-precipitate. Treatment with DNP: $\triangle$, cells; $\Delta$, PCAprecipitate.

and because active transport mechanisms for them occur in bacteria (Gale \& Folkes, I967; Gale, 1971) and higher organisms (Hokin \& Hokin, I963; Albers, 1967).

It was shown earlier (Fig. 2) that cells incubated in medium $M$ reached maximum aggregation-competence after $7 \mathrm{~h}$. Hence the rate of uptake of amino acids measured from 7 to Io $h$ is representative of aggregation-competent amoebae. Typical results for uptake of glutamate and lysine by exponential-phase amoebae are shown in Fig. 5 and 6. Aggregationcompetent amoebae behaved similarly. The amounts of amino acid taken up were calculated from the specific activity of the amino acid in the suspending medium. These values are accurate for initial rates of uptake into amoebae, but not for uptake into PCAprecipitable material because the specific activity of the amino acid inside the amoebae was probably different from that in the suspending medium. 

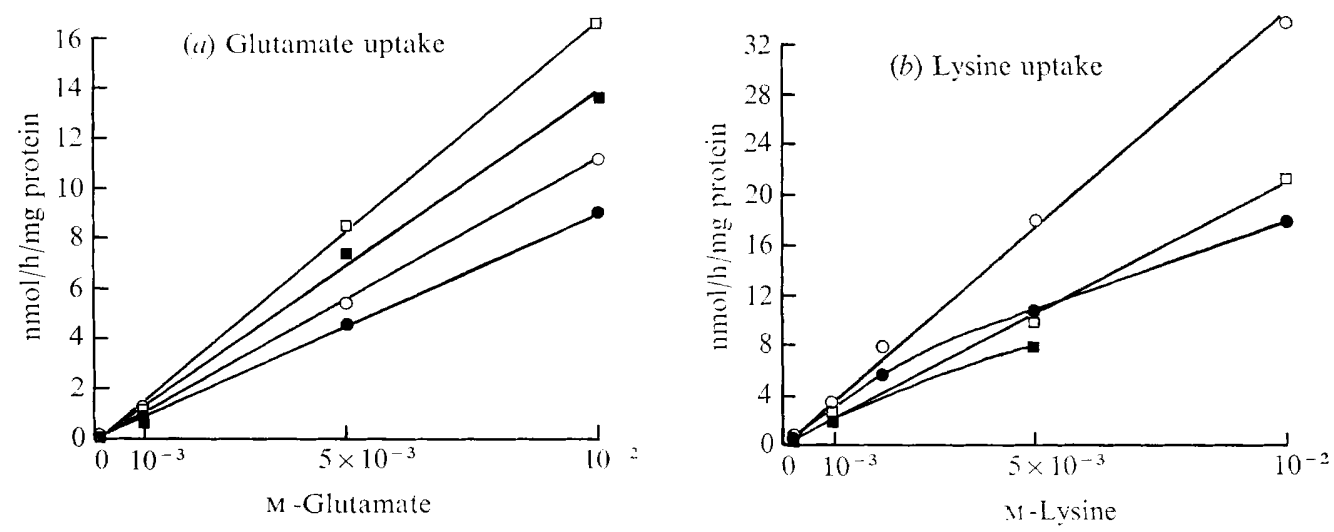

Fig. 7. Variation of rate of amino acid uptake with concentration of amino acid in the suspending medium. Exponential-phase amoebae and aggregation-competent amoebae (after $7 \mathrm{~h}$ incubation in suspension in medium $\mathbf{M}$ ) were incubated in dilute suspensions in medium $\mathbf{M}$ containing $\mathrm{L}-\left[\mathrm{U}-{ }^{14} \mathrm{C}\right]$ glutamate or $\mathrm{L}-\left[\mathrm{U}-{ }^{14} \mathrm{C}\right]$ lysine $(0.2 \mu \mathrm{Ci} / \mathrm{ml})$ at various concentrations. The rates of uptake were measured over a $3 \mathrm{~h}$ incubation period. Exponential-phase amoebae: 0 , total; 9 , PCAprecipitate. Aggregation-competent amoebae: $\square$, total; $\mathbf{\square}$, PCA-precipitate.

Chemical fractionation of cells (Roberts et al. 1955) after $3 \mathrm{~h}$ incubation in the presence of lysine or glutamate (I mM) showed that over $80 \%$ of the radioactivity in the PCAprecipitates was recovered in the protein fractions, but some conversion to other amino acids had taken place. The incorporation of lysine into the PCA-precipitate, but not into the pool was inhibited by 2,4-dinitrophenol (DNP) (Fig. 6) and cycloheximide (K.-C. Lee, unpublished). This suggests that uptake into the pool was passive, but the possibility that DNP altered membrane permeability cannot be ruled out. In bacteria, active transport of amino acid is usually dependent on the availability of an energy source, e.g. glucose (Gale \& Folkes, 1967). The presence of glucose was always stimulatory to uptake of amino acids into the pool of Dictyostelium discoideum, but not into PCA-precipitates. The stimulatory effect was usually small and variable, and was greater for lysine uptake (Fig. 6) than glutamate uptake (Fig. 5). This result is contrary to the report of Krichevsky \& Wright (I963) that glucose increased amino acid incorporation into proteins.

The relationship between external concentration of amino acid and rate of uptake by exponential phase and aggregation-competent amoebae is shown in Fig. 7. The uptake was linear over a $3 \mathrm{~h}$ incubation period except for uptake of glutamate at 5 and $10 \mathrm{~mm}$ by aggregation-competent amoebae. The initial rate is shown in these cases. Except for lysine incorporation into PCA-precipitate, the rates of uptake of the amino acids tested were directly proportional to the external amino acid concentrations, and there was no evidence of saturation kinetics characteristic of active transport. Exponential phase amoebae took up lysine faster than did aggregation-competent amoebae at all lysine concentrations tested. The converse was true for glutamate. This observation may reflect a difference in membrane properties, but this difference is unlikely to play a part in the control of differentiation because the amounts of amino acids taken up were very small. The amounts of radioactivity taken up in a $3 \mathrm{~h}$ incubation were less than $\mathrm{I} \%$ of that in the suspending medium and were comparable to, but smaller than, that expected for passive equilibration of the internal pool with the suspending medium. 

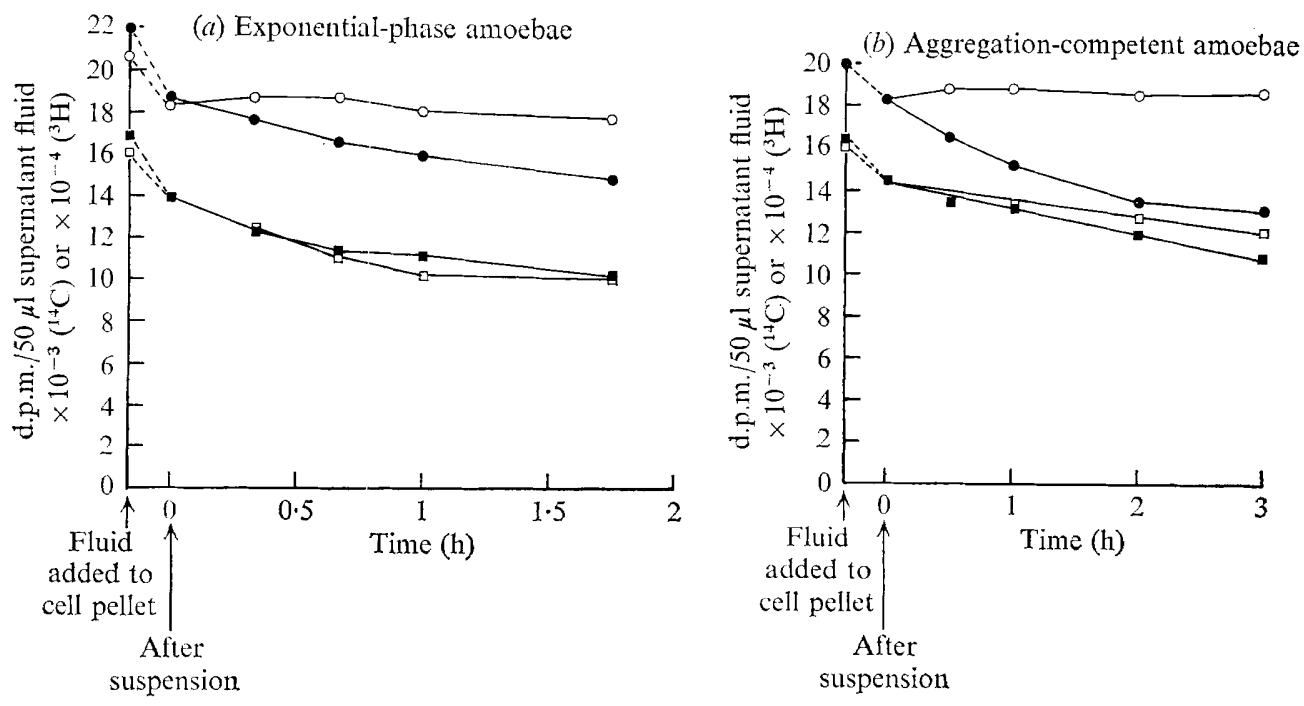

Fig. 8. Uptake of lysine and inulin in thick amoebal suspension. Exponential-phase amoebae and aggregation-competent amoebae (after $7 \mathrm{~h}$ in medium $\mathrm{M}$ ) were incubated in thick suspensions in the presence of $\mathrm{L}-\left[4,5^{3} \mathrm{H}\right]$ lysine (approx. I $\mu \mathrm{Ci} / \mathrm{ml}, \mathrm{I} \mathrm{mm}$ ) and carboxylic acid- $\left[{ }^{4} \mathrm{C}\right]$ inulin (approx. $0.2 \mu \mathrm{Ci} / \mathrm{ml}, 0.2 \mathrm{mg} / \mathrm{ml})$ with or without DNP $\left(5 \times 10^{-4} \mathrm{M}\right)$. Samples $(50 \mu \mathrm{l})$ of the supernatant fluid were taken for simultaneous measurement of carbon-14 and tritium. The concentrations refer to the fluid added to the cell pellet and not to the suspension. Carbon-r4 (inulin): 0 , control; O, +DNP. Titrium (lysine): $\mathbf{a}$, control; $\square,+$ DNP.

\section{Uptake of lysine in thick amoebal suspensions}

Passive diffusion was studied in a thick amoebal suspension in which the volume occupied by the amoebae accounted for a considerable proportion of the volume of the suspension. Uptake of amino acid or lysis of amoebae was indicated by a decrease in the radioactivity/ unit volume of the cell-free supernatant fluid. To check the latter possibility, a non-penetrating radioactive substance was present, and its radioactivity/unit volume of supernatant fluid was expected to remain constant during incubation. The substance used was inulin which has been used as an extracellular marker in Dictyostelium discoideum (Barravecchio, Baumann \& Wright, 1969; Garrod \& Born, I971).

Another complicating factor is aeration. The amoebae were suspended at a density of approximately $5 \times 10^{8} / \mathrm{ml}$, i.e. 25 times greater than their stationary-phase density, and aeration could be a limiting factor for an aerobic organism like Dictyostelium discoideum. Chemical fractionation of exponential-phase amoebae after a $3 \mathrm{~h}$ incubation with $\mathrm{L}$ [U- ${ }^{14}$ C]lysine (I mM) showed that only $29 \%$ of the total cell radioactivity was in PCAprecipitable material compared to about $75 \%$ for amoebae incubated in dilute suspension. This incorporation into PCA-precipitable material was insensitive to DNP $\left(5 \times 10^{-4} \mathrm{M}\right.$ in suspending medium) or cycloheximide ( $400 \mu \mathrm{g} / \mathrm{ml}$ in suspending medium) at such a high amoebal density. Amoebae in thick suspensions were probably not incubated under optimal conditions, and their permeability may be different from those in dilute suspensions. However, if amoebae after $3 \mathrm{~h}$ incubation in thick suspension were plated out on $2 \%(\mathrm{w} / \mathrm{v})$ agar, they would complete their development with little delay.

Typical uptake curves in thick suspensions showing reduction of radioactivity in the supernatant fluid are shown in Fig. 8. Contrary to expectation, the radioactivity due to inulin in the supernatant fluid fell at about the same rate as that due to lysine. This could 


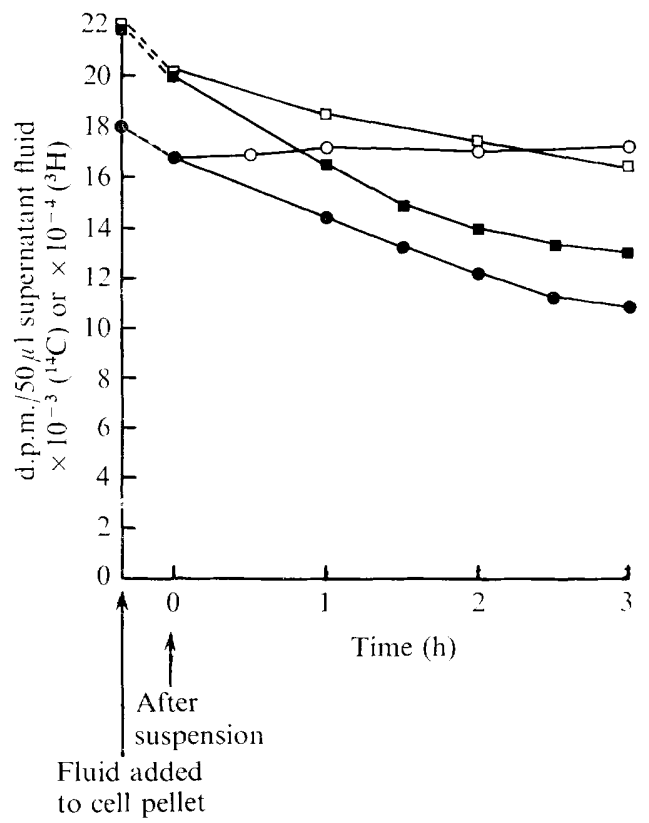

Fig. 9

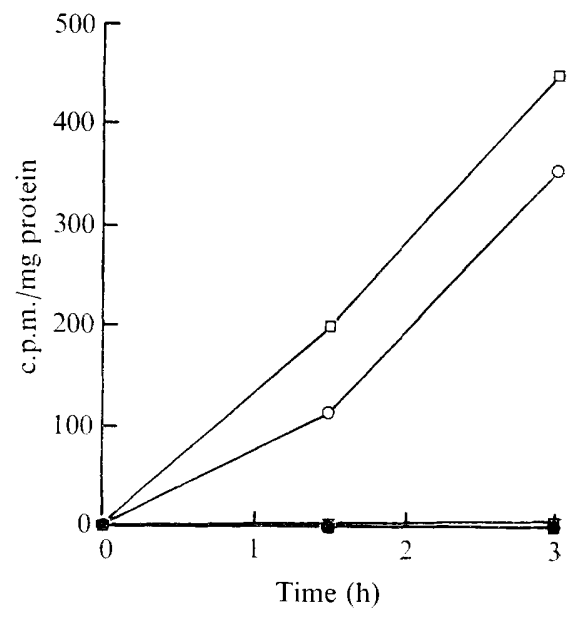

Fig. IO

Fig. 9. Effect of incubation at low temperature on the uptake of lysine and inulin in thick suspensions of exponential-phase amoebae. Experimental conditions were the same as those described in Fig. 8 with the exceptions that the incubation temperature was varied and that the concentration of $\mathrm{L}-\left[4,5{ }^{3} \mathrm{H}\right]$ lysine in the suspending fluid was approx. $\mathrm{I} \cdot 5 \mu \mathrm{Ci} / \mathrm{ml}$. Carbon-I 4 (inulin): $\bullet, 23{ }^{\circ} \mathrm{C}$; $\mathrm{O}, 4{ }^{\circ} \mathrm{C}$. Tritium (lysine): $\square, 23{ }^{\circ} \mathrm{C} ; \square, 4{ }^{\circ} \mathrm{C}$.

Fig. 10. Uptake of inulin in dilute amoebal suspensions. Exponential-phase and aggregationcompetent amoebae (after $7 \mathrm{~h}$ incubation in medium $\mathrm{M}$ ) were suspended at $10^{7}$ amoebae $/ \mathrm{ml}$ in medium $\mathrm{M}$ containing carboxylic acid- $\left[{ }^{14} \mathrm{C}\right]$ inulin $(0.2 \mu \mathrm{Ci} / \mathrm{ml}, 0.2 \mathrm{mg} / \mathrm{ml})$ with or without DNP $\left(5 \times 10^{-4} \mathrm{M}\right)$. The suspensions were incubated at $23^{\circ} \mathrm{C}$ in a reciprocal shaker $(80 \mathrm{cycles} / \mathrm{min})$. At intervals, amoebae were harvested for estimation of radioactivity in cells and material precipitable by $10 \%(w / v)$ TCA using a gas-flow counter.

Exponential-phase amoebae. Control: $\bigcirc$, total amoebae; ๑, TCA-precipitate. +DNP: $\triangle$, total amoebae; $\Delta$, TCA-precipitate.

Aggregation-competent amoebae. Control: $\square$, total amoebae; $\mathbf{\square}$, TCA-precipitate. + DNP: $\nabla$, total amoebae; $\nabla$, TCA-precipitate.

On the scale used, $\boldsymbol{\bullet}, \triangle, \boldsymbol{\Delta}, \boldsymbol{\square}, \boldsymbol{\nabla}$ and $\nabla$ are superimposed because they all give values close to zero.

not be accounted for by cell breakage because lysis was negligible $(<0 . \mathrm{I} \%)$. In the presence of DNP, lysine uptake was affected very slightly, but inulin uptake was completely inhibited. The presence of cycloheximide $(400 \mu \mathrm{g} / \mathrm{ml})$ or glucose $(\mathrm{I} \cdot 5 \%, \mathrm{w} / \mathrm{v})$ in the suspending medium had little effect on the uptake of both lysine and inulin (K.-C. Lee, unpublished), but low temperature abolished inulin uptake and slowed down lysine uptake (Fig. 9). These results are consistent with active transport of inulin and passive diffusion of lysine.

Since thick suspensions do not provide optimal incubation conditions for the amoebae, it was necessary to demonstrate active inulin uptake in dilute suspensions. This is shown in Fig. IO. Preliminary experiments demonstrated that, at the concentration used, carboxylic acid- $\left[{ }^{14} \mathrm{C}\right]$ inulin was soluble in $10 \%(\mathrm{w} / \mathrm{v})$ trichloroacetic acid (TCA) and was completely recovered in the pool fraction. It is evident from Fig. Io that both exponential-phase and aggregation-competent amoebae took up inulin, and the uptake was abolished by DNP. The rate of uptake was higher for aggregation-competent amoebae both on the basis of 


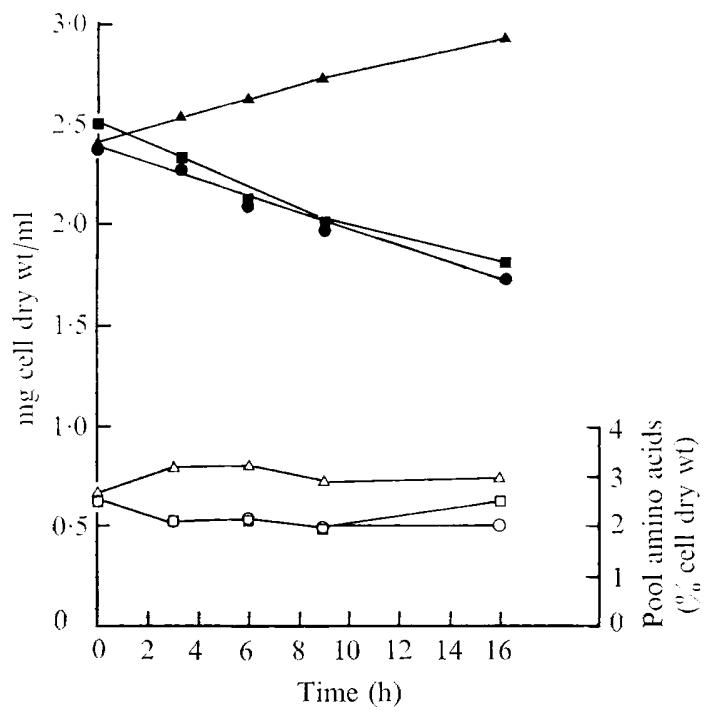

Fig. 11. Changes in dry weight and amino acid pool of amoebae incubated in the presence of nutrients. Exponential-phase amoebae were incubated in dilute suspension in medium $\mathbf{M}$ containing either a mixture of glucose, amino acids and vitamins (full nutrient mixture) (Table I) or a mixture of amino acids and vitamins (no glucose). At intervals, samples were taken for determination of dry weight (Fig. 3), and the pool amino acids extractable with ice-cold $5 \%(\mathrm{w} / \mathrm{v}$ ) TCA were determined after removal of TCA by ether extraction. An average molecular weight of $1 \mathrm{I} 7$ (determined from the pool amino acid composition of exponential-phase cells) was used for calculations. The level of pool amino acids extracted with TCA from control amoebae was slightly lower than that extracted with hot water (Fig. 4). Cell dry weight: $\mathbf{O}$, control; $\boldsymbol{\Delta}$, + full nutrient mixture; $\mathbf{\square},+$ amino acids and vitamins. Pool amino acid content: $\bigcirc$, control; $\triangle,+$ full nutrient mixture; $\square$, + amino acids and vitamins.

Table I. Nutrient mixture for inhibition of aggregation in submerged static culture

Final concentrations in Petri dishes

(i) Glucose $\mathrm{I} \cdot 62 \%(\mathrm{w} / \mathrm{v})$

(ii) Amino acid mixture (mM)

$\begin{array}{llll}\text { Asp } 2.43 & \text { Thr } 0.94 & \text { Ser I } \cdot 80 & \text { Glu } 4.96 \\ \text { Pro } 2.82 & \text { Gly } \mathrm{I} \cdot \mathrm{I} 7 & \text { Ala } \mathrm{I} \cdot 37 & \text { Val } 0.93 \\ \text { Met } 0.43 & \text { Ile } 0.48 & \text { Leu I.45 } & \text { Tyr } 0.26 \\ \text { Phe } 0.48 & \text { Lys } \mathrm{I} \cdot 48 & \text { His } 0.30 & \text { Arg } 0.39\end{array}$

Total: $2 \mathrm{I} \cdot 7$ (adjusted to $\mathrm{pH} 6 \cdot 0$ with $\mathrm{I} \mathrm{M}-\mathrm{NaOH}$ ).

(iii) Vitamin mixture $(\mu \mathrm{g} / \mathrm{ml})$

Biotin, 0.02 ; calcium pantothenate and folic acid, 6.00; pyridoxine, nicotinic acid, inositol, thiamine, $p$-amino-benzoic acid, $66 \cdot 0$.

cell protein (Fig. 10) and cell volume (Fig. 8). This might have been caused by the smaller size and hence greater surface area per unit volume or protein content of aggregationcompetent amoebae. The radioactivity taken up was not incorporated into TCA-precipitable material, and gel filtration through Sephadex G-50 showed no degradation of the inulin taken up during the $3 \mathrm{~h}$ incubation period. 


\section{Inhibition of aggregation by nutrients}

It appears that, under the experimental conditions used, Dictyostelium discoideum did not have effective mechanisms for retention of metabolites or active transport of amino acids. If the leakage of metabolites contributes in some way to the initiation of differentiation, the amoebae will not differentiate when nutrients are present in sufficient concentration to offset losses due to leakage, but will do so in a non-nutrient medium where lost metabolites cannot be replaced. The formation of streams and aggregation centres in static submerged culture in medium $M$ was inhibited in the presence of a mixture of glucose, together with an amino acid mixture with the same composition as casein hydrolysate and vitamins at the same concentrations as Ashworth's (unpublished) partially defined growth medium for $D$. discoideum AX-3 (Table I). Aggregation was not inhibited in the presence of either glucose alone or amino acids plus vitamins at twice the concentrations given in Table I (without glucose). Krichevsky \& Wright (1963) reported that glucose increased the 'rate of development' on agar, but very little effect on the rate of aggregation was observed here in static submerged culture.

Changes in cell dry weight and pool amino acid content of amoebae incubated in medium $\mathrm{M}$ with additions of nutrients are shown in Fig. II. In the presence of amino acids and vitamins, the cell dry weight decreased at a rate similar to the control (no added nutrients), and there was no difference between the pool amino acid contents. In contrast, amoebae incubated with glucose, amino acids and vitamins (full nutrient mixture) showed a slight increase in dry weight, and the pool amino acid content rose to a level $50 \%$ higher than that of control amoebae.

\section{DISCUSSION}

Dictyostelium discoideum amoebae released large amounts of low molecular weight metabolites into the suspending medium during the pre-aggregation period. These metabolites accounted for the bulk of the protein and phosphorus lost from cells, and it is surprising that they were released at a time when they were most needed, i.e. during starvation. These experiments were performed on cell suspensions, and it is not certain to what extent the findings apply to cells incubated on Millipore filters or agar surface. Cells incubated under these conditions have at the most a thin layer of liquid on their surfaces, and they are not in intimate contact with the liquid in the support pads or agar. However, it is probable that cells incubated on Millipore filters release soluble compounds because the liquid in the support pads showed great increases in conductivity during incubation (Garrod \& Gingell, I970; K. -C. Lee, unpublished). The leakage of metabolites from cells is probably not caused by depletion of the energy supply essential for a hypothetical activetransport process because the amoebae were grown in glucose-containing medium and had ample stores of glycogen (Ashworth \& Watts, 1970). The uptake of the amino acids studied, and probably others, is passive. Hence the simplest explanation for leakage of metabolites is that the amoebae possessed no mechanism for active uptake or retention of amino acids and nucleotides, and maintenance of metabolite concentrations in the pool at levels compatible with survival requires catabolism of protein and RNA.

The absence of an active transport mechanism for amino acids is not a great handicap to survival in the wild because the amoebae usually obtain their nutrients by engulfing bacteria. Dictyostelium discoideum amoebae are capable of ingesting other particulate materials, e.g. ion exchange resins (Farnsworth \& Wolpert, 197I), but the ability to take up a small molecule like inulin (mol. wt 5000) actively (probably by pinocytosis) is unusual. 
This could be related to the ability of $D$. discoideum $\mathrm{AX}-2$ to grow in a proteose peptoneyeast extract medium which contains peptides of low molecular weight. An analogous situation was reported in the amoeba Acanthamoeba castellanii, which actively ingests polystyrene beads, but does not transport small molecules actively (Korn \& Weisman, I967; Weisman \& Korn, I967; Korn \& Olivecrona, I971).

The initiation of differentiation is complex and is probably influenced by concentrations of intermediary metabolites which in turn depend on the nature of nutrients available. Whether cells proliferate or differentiate depends on the availability of a balanced diet of nutrients at sufficient concentrations to counterbalance losses due to leakage. It was shown in Fig. I t that when amoebae were incubated in the presence of a nutrient mixture (glucose, amino acids and vitamins) capable of inhibiting aggregation, the pool amino acid content was higher than that of amoebae incubated in the absence of added nutrients. This observation is consistent with the hypothesis that the initiation of differentiation is associated with irreplaceable loss of metabolites from amoebae leading to a lower pool amino acid content, but does not prove it. The high pool amino acid content cannot be maintained by the presence of amino acids and vitamins in the suspending medium. Glucose is required, but glucose alone does not inhibit aggregation. It is likely that this effect of glucose is associated with the production of intermediary metabolites rather than energy mediated uptake of amino acids.

I am indebted to Dr D. Kerridge, Professor E. F. Gale and colleagues in the SubDepartment of Chemical Microbiology for their interest, advice and encouragement, and to the Wellcome Trust for financial support.

\section{REFERENCES}

Albers, R. W. (1967). Biochemical aspects of active transport. Annual Review of Biochemistry 36, 727-756. Ashworth, J. M. \& WatTs, D. J. (1970). Metabolism of the cellular slime mould Dictyostelium discoideum grown in axenic culture. Biochemical Journal II9, I 75-I 82.

Barravecchio, J., Baumann, P. \& Wright, B. E. (1969). Cell volume determinations of Dictyostelium discoideum. Applied Microbiology 17, 64I-642.

BONNER, J. T. (1947). Evidence for the formation of cell aggregates by chemotaxis in the development of the slime mould Dictyostelium discoideum. Journal of Experimental Zoology 1o6, I-26.

Bonner, J. T. (1967). The Celílar Slime Molds, and edn. Princeton, New Jersey: Princeton University Press.

FARnsworth, P. A. \& Wolpert, L. (I97I). Absence of cell sorting out in the grex of the slime mould Dictyostelium discoideum. Nature, London 231, 329-330.

Gale, E. F. (1971). 'Don't talk to me about permeability.' Journal of General Microbiology 68, I-I4.

Gale, E. F. \& FolKes, J. P. (I967). The effect of lipids on the accumulation of certain amino acids by Staphylococcus aureus. Biochemica et biophysica acta $\mathbf{1 4 4}, 46 \mathrm{I}-466$.

GaRrod, D. R. \& BorN, G. V. R. (I97I). Effect of temperature on the mutual adhesion of preaggregation cells of the slime mould Dictyostelium discoideum. Journal of Cell Science 8, 75I-765.

Garrod, D. R. \& Gingell, D. (1970). A progressive change in the electrophoretic mobility of preaggregation cells of the slime mould Dictyostelium discoideum. Journal of Cell Science 6, 277-284.

GERISCH,G.(1962). Zellfunktionen und Zellfunktionswechsel in der Entwicklung von Dictyostelium discoideum. IV. Der Zeitplan der Entwicklung. Wilhelm Roux Archiv für Entwicklungsmechanik der Organismen $\mathbf{1 5 3}$, $603-620$.

Gerisch, G. (1968). Cell aggregation and differentiation in Dictyostelium. In Current Topics in Developmental Biology, vol. 3, pp. I 57-197. Edited by A. A. Moscona \& A. Monroy. New York \& London: Academic Press.

Hokin, L. E. \& Hokin, M. F. (1963). Biological transport. Annual Review of Biochemistry 32, 553-578.

Korn, E. D. \& Olivecrona, T. (I97I). Composition of an amoeba plasma membrane. Biochemical and Biophysical Research Communications 45, 90-97. 
Korn, E. D. \& Weisman, R. A. (1967). Phagocytosis of latex beads by Acanthamoeba. II. Electron microscopic study of the initial events. Journal of Cell Biology 34, 219-227.

Krichevsky, M. I. \& Love, L. L. (1965), Efflux of macromolecules from washed Dictyostelium discoideum. Journal of General Microbiology 4r, 367-374.

Krichevsky, M. I., Love, L. L. \& Chassy, B. M. (I969). Acceleration of morphogenesis in Dictyostelium discoideum by exogenous mononucleotides. Journal of General Microbiology 57, 383-389.

KricheVSKY, M. I. \& WRIGHT, B. E. (1963). Environmental control of the course of development in Dictyostelium discoideum. Journal of General Microbiology 32, 195-207.

LELOIR, L. F. \& CARDINI, C. E. (1957). Characterization of phosphorus compounds by acid lability. Methods in Enzymology 3, 840-850.

Lowry, O. H., Rosebrough, N. J., Farr, A. L. \& Randall, R. J. (195I). Protein measurement with the Folin-Phenol reagent. Journal of Biological Chemistry 193, 265-275.

Mitchell, P. (1953). Transport of phosphate across the surface of Micrococcus pyogenes: Nature of the cell 'inorganic phosphate'. Journal of General Microbiology 9, 273-287.

Munro, H. N. \& Fleck, A. (I966). The determination of nucleic acids. Methods of Biochemical Analysis I4, II3-176.

Newell, P. C. (197I). The development of the cellular slime mould Dictyostelium discoideum: A model system for the study of cellular differentiation. Essays in Biochemistry 7, 87-I 26.

Newell, P. C., Longlands, M. \& Sussman, M. (197I). Control of enzyme synthesis by cellular interaction during development of the cellular slime mould Dictyostelium discoideum. Journal of Molecular Biology 58, 54I-554.

Pannbacker, R. G. (1967). Uridine diphosphoglucose biosynthesis during differentiation in the cellular slime mold. I. In vivo measurements. Biochemistry 6, 1283-1 286.

Roberts, R. B., Abelson, P. H., Cowie, D. B., Bolton, E. T. \& Britten, R. J. (1955). In Studies of Biosynthesis in Escherichia coli, pp. I3-30. Publication no. 607. Washington: Carnegie Institution.

RoSEN, H. (1957). A modified ninhydrin colorimetric analysis for amino acids. Archives of Biochemistry and Biophysics 67, 10-15.

Sargent, D. \& Wright, B. E. (1971). Trehalose synthesis during differentiation in Dictyostelium discoideum. II. In vivo flux determinations. Journal of Biological Chemistry 246, 5340-5344.

Schwalb, M. \& Roth, R. (1970). Axenic growth and development of the cellular slime mould, Dictyostelium discoideum. Journal of General Microbiology 6o, 283-286.

Stanton, M. G. (1968). Colorimetric determination of inorganic phosphate in the presence of biological material and adenosine triphosphate. Analytical Biochemistry 22, 27-34.

Sussman, M. (1968). In 'Open discussion'. An analysis of metabolism underlying differentiation in Dictyostelium discoideum (by B. E. Wright). Journal of Cellular Physiology 72 (Suppl. I), 145-160.

Sussman, M. \& Sussman, R. R. (1969). Patterns of RNA synthesis and of enzyme accumulation and disappearance during cellular slime mould cytodifferentiation. Symposium of the Society for General Microbiology 19, 403-435.

Watts, D. J. \& Ashworth, J. M. (1970). Growth of myxamoebae of the cellular slime mould Dictyostelium discoideum in axenic culture. Biochemical Journal II9, I7I-I 74 .

Weisman, R. A. \& Korn, E. D. (1967). Phagocytosis of latex beads by Acanthamoeba. I. Biochemical properties. Biochemistry 6, 485-497.

White, G. J. \& Sussman, M. (196I). Metabolism of major cell constituents during slime mold morphogenesis. Biochemica et biophysica acta 53, 285-293. 